\title{
Spiritually Formed Interventions in Crisis Intervention by Christian Female Social Workers ${ }^{1}$ Jan Kaňák
}

\begin{abstract}
The article deals with factors that influence the application of spiritually formed interventions in professionally conceived crisis intervention. These interventions are done by female social workers who participated in research on the encounter of spiritual and professional discourse. The text describes the theoretical anchorage of discursive clashes and presents problems with professional discourse in social work. Subsequently, the spiritually formed interventions used by communication partners and the factors that influence their selection are described, as well as the three variants that are the result of the interaction of these factors.
\end{abstract}

Keywords: spirituality, spiritually sensitive interventions, spiritually oriented interventions, social work, crisis intervention

\section{Introduction}

The article focuses on the question: Why (that is, what factors influence such a choice) do Christian female social workers choose a spiritually formed intervention in situations where professional and spiritual discourse clashes in the context of crisis intervention? The question raised is based on more general research. This research focused on the process of social work practice ${ }^{2}$ in crisis intervention (specifically, in situations marked as clashes between professional and spiritual discourse). The text is based on dealing with spiritually sensitive and spiritually oriented interventions which are described in more detail elsewhere. ${ }^{3}$ The texts that deal with spiritual interventions are mostly descriptive in nature (they describe the intervention as such, or the limits of its usage). ${ }^{4}$ Taking into account this fact, I consider it appropriate to complement this static character with a dynamic one. As the spiritually formed interventions are related to the situation of a clash between

1 This article was supported by the grant Nové výzvy a nová řešení ve veřejné politice a sociální práci (MUNI/A/0784/2017).

2 I see social work as a continuous re-construction of activities carried out by social workers with respect to their own concept of social work (meaning, goals, tasks, definition...), specific client system (client and its surroundings), organisational context (values and rules of organisation), and (in the case of believing workers) with respect to their own spirituality in situations of a concrete meeting with a client.

3 Jan KAŇÁK, Nedefinovaná profesionalita: Vztah diskursů spirituality a profesionality v sociální práci v soudobé odborné literatuře, Sociální práce / Sociálna práca 5/2016, pp. 72-92.

4 Cf. Edward R. CANDA and Leola D. FURMAN, Spiritual Diversity in Social Work Practice: The Heart of Helping, Oxford: Oxford University Press, 2010; Ann M. CALLAHAN, Spirituality and Hospice Social Work, New York: Columbia University Press, 2017; David S. DEREZOTES, Spiritually Oriented Social Work Practice, Boston: Allyn and Beacon, 2006; and others. 
professional and spiritual discourse, I will also deal with this concept. Then I will describe the methodological framework of the research and its limits. The last part of the article will try to answer the abovementioned question. The importance of spirituality in the context of social work will be taken here as a precondition which does not need to be discussed. I am also aware of the fact that not everyone would accept it (this is true even with regard to the development of the relationship between professionalism and spirituality in our country where the nature of the relationship is still searched for). ${ }^{5}$

\section{The Situation of a Clash between Professional and Spiritual Discourse}

The topic of discursive clashes is, in my opinion, very up-to-date in social work. The nature of professional discourse is changing (that is, the various concepts of professionalism and their mutual contact can be seen as discursive clashes). At the same time, the concrete form of practically implemented social work depends on the outcome of various (more or less intense) discourse clashes (that is, the clashes between various types of discourse). ${ }^{6}$ It is usual for social work that, in individual situations, various types of discourses come into conflicts (for example, legal discourse with discourse of ethics of care, ${ }^{7}$ professional discourse with managerial discourse, ${ }^{8}$ or professional discourse with discourse of spirituality and religion). ${ }^{9}$ Social workers can experience legal situations (to report a criminal offense, in this case abuse of a person in care, or to respect the confidentiality of information). There could be situations in which they have to make various decisions (Should we respect the direction of the management of the organisation about the length of contact with the client or to follow their own concept of social work? Should we pray with a client or not? And so on.).

These situations can be described as discursive clashes. They can be defined as situations in which two or more discourses meet and interact - they influence each other. ${ }^{10}$ This influence appears not only in communication or interaction but also within the framework of internal dialogue (for example, in situations where a worker considers the next step in some process). It is also necessary to point out that these clashes are situational. In some situations, there could be clashes. In other situations, though, workers follow one specific discourse even if some other discourse could be useful or crucial for the next procedure. Baxter ${ }^{11}$ introduces the general course of the two discourse clashes. The author formulates three possible courses of such clashes (Table 1 below). Both discourses are accepted as valid for the next construction situation, and, in addition, they create a new discourse in which they are hard to recognise. This variant is referred to as transformation by the author. In both of the incoming discourses, there are centripetal dynamics - a shift to the centre of another construction and acceptance of discourses.

Cf. Jan KAŇÁK, Postavení diskursu spirituality v sociální práci, Sociální práce / Sociálna práca 4/2015, pp. 30-46.

6 Cf. Karen HEALY, Social Work Theories in Context, London: Palgrave Macmillan, 2014; Jan KAŇÁK, Diskursivní paleta sociální práce: reflektování diskursů spirituality pomocí prvků diskursivní analýzy, in: Sociální práce v nejisté době, eds. Ondřej ŠTECH, Peter PATYI and Zuzana TRUHLÁŘOVÁ, Hradec Králové: Gaudeamus, 2016, pp. 23-29; Catherine McDONALD, Challenging Social Work: The institutional context of practice, London: Palgrave Macmillan, 2006; and others.

7 Cf. Radka JANEBOVÁ, Dilema mezi právem a etikou aneb právo nezbavuje odpovědnosti, in: Etika sociální práce, ed. Miroslav KAPPL, Martin SMUTEK and Zuzana TRUHLÁŘOVÁ, Hradec Králové: Gaudeamus, 2010, pp. 38-54.

8 Cf. McDONALD, Challenging...

9 Cf. KAŇÁK, Postavení..

10 Cf. Leslie A. BAXTER, Voicing Relationships: A Dialogic Perspective, London: SAGE, 2011.

11 Ibid., pp. 120-151. 
Table 1: Discourse Clashes and their Variants

\begin{tabular}{|l|l|l|l|}
\hline Process & Dynamics d1 & Dynamics d2 & The result of clashes \\
\hline $\begin{array}{l}\text { Transforma- } \\
\text { tion }\end{array}$ & Centripetal & Centripetal & $\begin{array}{l}\text { There is a new discourse. The origi- } \\
\text { nal two discourses are not recogni- } \\
\text { sable in the new one. }\end{array}$ \\
\hline $\begin{array}{l}\text { Synchronous } \\
\text { co-playing }\end{array}$ & Centripetal & Centripetal & $\begin{array}{l}\text { There is a discourse in which both } \\
\text { original discourses are accepted, but } \\
\text { they are distinguishable. }\end{array}$ \\
\hline $\begin{array}{l}\text { Diachronic } \\
\text { separation }\end{array}$ & $\begin{array}{l}\text { Centripetal / } \\
\text { centrifugal }\end{array}$ & $\begin{array}{l}\text { Centripetal / } \\
\text { centrifugal }\end{array}$ & $\begin{array}{l}\text { Only one discourse wins, another } \\
\text { situation is constructed in accor- } \\
\text { dance with it. }\end{array}$ \\
\hline
\end{tabular}

In the second, more general, variant, there are also centripetal dynamics in both incoming discourses. And although both discourses are present in the construction of the next interaction or situation, it is possible to recognise the discourses during a synchronous co-playing in this situation. One of them is usually more dominant. Nevertheless, both of them are present. These variants are governed by the principle of non-zero sums, that is, it means that both discourses profit. Compared to them, the last, more general, variation of the dynamics of clashes is characterised by 'zero sum logic. ${ }^{12}$ In one discourse, the centripetal dynamics manifests itself. The second one is characterised by the centrifugal dynamics, and it is exempted from further construction process. The further process then is in accordance with the winning discourse. This variant is referred to as diachronic separation by the author.

The result of the clash between professional and spiritual discourse influences the use of spiritually formed interventions. Generally, it is possible to distinguish purely professional social work (which is, in this context, characterised by leaving spirituality outside the office door - that is, the worker does not deal with the client's spirituality) and purely spiritual activity (the social worker deals entirely with the client's spirituality). Further, spiritually sensitive and spiritually oriented social work should be distinguished. In the case of spiritually sensitive social work, spirituality is treated as any other factor of social functioning or reflexive life management of clients. Spirituality is thus rather verbalised and (simply said) rationalised in the process of social work practice. Moreover, it is assumed that one part of social work practice should also be the influence on the client's spirituality. In the case of spiritually oriented social work, the client's spiritual development is a part of social work practice and expected activities (if a worker and his client agree on it). ${ }^{13}$ This distribution is, to some extent, not entirely satisfying when describing the dynamics of the choice of spiritually formed interventions (as will be shown below). I will, therefore, extend it by a spiritually oriented concept.

\section{Problems with Professional Social Work Discourse}

It is rather complicated to define the spirituality discourse in social work. It depends on the dimension of religion and the related concept of spirituality and their share in social work. ${ }^{14}$ On

12 BAXTER, Voicing..., p. 138.

13 Cf. KAŇÁK, Nedefinovaná..

14 Cf. CANDA and FURMAN, Spiritual Diversity ..., pp. 60-61. 
the other hand, there are relatively fewer difficulties with it than with the professional discourse. Before I start dealing with these problems with the professional discourse of social work, it is necessary to say that, for this work, I identify the spiritual discourse with the Christian view. The Christian view could be characterised as 'the experience of transformation in the relationship of a person and God (the same way as it was shown in the life of Jesus Christ). It is also the inspiration of Holy Spirit. Christian spirituality is seen as a lifestyle which includes all relationships'. ${ }^{15}$ There is no such definition (with a relative conformity) for the professional discourse.

The different concepts of professional discourse include sociological statements about the profession and its meaning. Also, there are approaches where professionalism is associated with 'focusing on the quality of practice' and is emphasised in 'the framework of agreed or accepted' interventions. ${ }^{16} \mathrm{At}$ the same time, its form is (to some extent) constantly negotiated in the interactions of social workers with each other and in the interactions with other fields. ${ }^{17}$ The situation led Payne into doubts. He doubted the fact that the 'knowledge and value base' of social work defines its professionalism. $\mathrm{He}$ also disagreed with the fact that such a base would make social work different 'from other professions. ${ }^{18}$ While the modern concept of professional discourse (still present in the context of social work) defines professionalism through external criteria (the possibility of self-regulation, awareness of one's mission, autonomy, own educational institutions, etc., and also, for some, systematic theory or code of ethics), ${ }^{19}$ the postmodern concept of professional discourse usually defines it from the inside, that is, it is defined by specific social workers themselves, or (in the case of managerial concept of professionalism) by the management of the organisation or services. Thus, the concepts of professionalism have emerged. It has been viewed as an unstable negotiation process (professionalism is constructed in discussions between social workers within their organisations, or between them and other professionals; it is open to other discourses and perspectives), as an emerging and developing learning through practice, or as the ethics of virtue (the content of the term professional is constructed by social workers who are perceived and recognised as an authority).$^{20}$

This affects the suitable way of dealing with the clashes between professional and spiritual discourse in social work. In the modern perspective of professional discourse, there are two different discourses. For some postmodern concepts, though, it is not so clear. Healy, for example, does not define the professional discourse and assumes that a combination of different discourses is involved in professional social work. ${ }^{21}$ From some points of view, it can be assumed that spiritually formed interventions can be seen as a part of the professional discourse. However, for the purposes of this text, I will consider spiritually formed interventions to be placed outside the professional discourse (associated with the scientific understanding of the world).

15 Donald B. PERRIN, Studying Christian Spirituality, New York: Routledge, 2007, p. 32.

16 Cf. Jon NIXONT et al., Toward a Learning Profession: Changing Codes of Occupational Practice within the New Management Education, British Journal of Sociology of Education 1/1997, pp. 6-14.

17 Cf. Andy HARGREAVES, Four Age of Professionalism and Professional Learning, Teachers and Teaching. History and Practice 2/2000, pp. 151-182.

18 Malcolm PAYNE, What is Professional Social Work, Bristol: The Policy Press, 2006, p. 152.

19 Ernest GREENWOOD, Attributes of Profession, Social Work 3/1957, pp. 45-55; Robert L. RHODES, Professionalism: A Review of Its Impact on the Health Services, Orthotics and Prosthetics 4/1984, pp. 69-74; Harold L. WILENSKY, The Professionalization of Everyone, The American Journal of Sociology 2/ 1964, pp. 137-158.

20 Cf. Julia EVETTS, The Concept of Professionalism: Professional Work, Professional Practice and Learning, in: International Handbook of Research in Professional and Practice-based Learning, ed. Stephen BILLET, Christian HARTEIS and Hans GRUBER, New York: Springer, 2014, pp. 29-56; Ondřej FISCHER, Potřebuje slušně vychovaný sociální pracovník zákon o sociálních službách?, in: Profesionalita, perspektivy a rozvoj sociální práce, eds. Zuzana TRUHLÁŘOVÁ and Katarina LEVICKÁ, Hradec Králové: Gaudeamus, 2013, pp. 115-122; HARGREAVES, Four...; Nigel, M. VERRALL, Social Work Practice and Competing Philosophies, Neo: A Journal of Student Research 1/2010, pp. 1-12; and others. 


\section{Spiritually Formed Interventions}

Spiritually formed interventions can be seen as a specific manifestation of the spiritual discourse in social work. The degree of discourse impact consequently influences the whole process. Either the spiritual level of a specific client is primarily addressed (spiritually oriented), or whether the social worker primarily focuses on reflexive life management or social functioning (spiritually sensitive). In the first case, the purpose of the interventions is to promote spiritual growth (which is, in the context of spiritually oriented social work, seen as an integral part of social work). In the latter case, the purpose is to deal with the client's situation (spiritual growth is perceived as a part of the work of other professionals, that is, pastoral advisors, priests, pastors or rabbis, etc.). Before the introduction of individual interventions (classified either as spiritually sensitive or spiritually oriented), I will also briefly discuss a problem of how social workers can integrate these interventions into a set of acceptable interventions. I understand this set as the total range of interventions, techniques, activities, and actions that social workers consider acceptable and appropriate in terms of social work practice.

Basically, there are two more general ways of incorporating spiritually formed interventions into a set of acceptable ones. The first is the knowledge and skills acquirement in education and training, and the second is the tendency towards 'professionalism which integrates faith'. In this process, 'the integration of faith and knowledge'22 takes place. In this case, authors refer to the process where the spiritual level is gradually integrated into the knowledge base of social work (built on a professional discourse) through one's own experience with spirituality (that is, in the case of the text presented here, intervention based on the spiritual level). While, in the first case, spiritually anchored interventions (as well as the possibilities of their use for social work practice) are referred to by authorities or other people, in the latter case, two matters - the integration of one's own experiences with spirituality and one's own conception of spirituality - influence the decision about acceptable procedures for social workers' practice. The following distribution of spiritually sensitive and spiritually oriented interventions is based on an analysis of 74 expert sources (articles, monographs, and conference proceedings). This analysis is discussed in more detail in another text. ${ }^{23}$ Spiritually sensitive interventions include: the creation of a space in which clients experience the acceptance of their spirituality; continuous dealing with the importance of clients' spirituality and the situation experienced; negotiating the degree of spirituality in the service delivery process; perceiving spirituality as a source of functional and non-functional reflexive life coping, or as a source of social functioning; spiritual texts recommendation; and spiritual practice as a support in the perceived situation, or support during contact with the clergy (if the experienced situation touches the area of spiritual growth more strongly). The spiritually oriented interventions include, in addition to spiritual assessment (that is, assessment of the importance of spirituality for the client and the situation experienced), cooperation with clients in the forgiveness process (that is, forgiving those who have somehow hurt clients), praying with and for clients, and supporting clients in spiritual growth.

22 Susan EVANS and Glenda DEVLIN, Client-led Spiritual Interventions: Faith-integrated Professionalism in the Context of Christian Faith-based Organization, Australian Social Work 3/ 2016, p. 16. 


\section{Basic Description of Methodological Framework}

The abovementioned question of this text is formulated in connection with the realised qualitative research. This research dealt with the construction of social work practice during clashes of professional and spiritual discourse in crisis intervention (from the perspective of female social workers ${ }^{24}$ who perceive themselves as Christians without the need for active participation in the Church). The following conditions were set for the criterion selection of communication partners: a) active performance of crisis intervention for at least two years (at least half a year in some organisations), b) perceiving oneself as a Christian, and c) social worker status - both in self-concept and in education. Communication partners were contacted in those organisations that provided crisis intervention in outpatient form at least five days a week and did not work with a more specific target group (e.g., victims of domestic violence, etc.). Willingness to participate in the research and, at the same time, the fulfilment of these conditions ultimately led to a small sample $(\mathrm{N}=6)$. Thus, this part of the research output (and not only this one) is recognised as one of a qualitative research line based on small sample sizes. ${ }^{25}$

Data were created in semi-structured interviews from 3/2018 to 7/2018. In parallel, the data were analysed (another analysis along with several additional interviews was then carried out during an additional period from 8/2018 to the beginning of 9/2018). The part of the research output presented here is based on elements of a constructivist variant of grounded theory. ${ }^{26} \mathrm{In}-$ itial interviews (followed by additional shorter interviews) lasted between 96 and 184 minutes. The communication partners work in three organisations, one of which is church-founded (and it is closer to spiritual discourse). The research relied on the critical incident technique. This technique is based on describing one particular case that relates to the topic under investigation. Our small sample and the use of the critical incident technique are more significant limits of the presented outputs. Both limiting factors could influence the scope of the described spiritually formed interventions. These could also be influenced by the punctuality and variety of factors that influence their selection during social work practice. The limits are, to a certain extent, counterbalanced by the different spiritual background of communication partners (Catholic, Evangelical, Hussite, without further specification) and also by the implementation of additional interviews.

The data was recorded with an mp3 player with the recorder function. Then it was literally transcribed. After a very cursory reduction of the first order, the transcripts were copied to the ATLAS.ti version 7. 5. 18. In this program, they were encoded (the encoding was not strictly according to line-by-line coding). The findings presented here are part of the Interaction Model of Integration of Spirituality (IMIS). IMIS emerged from broader research which is going to be presented in professional periodicals and conferences.

24 This is about female social workers only as only women were involved in the research, even though it was not a criterion of the survey unit.

25 Cf. Ana CARAS and Antonio SANDU, The Role of Supervision in Professional Development of Social Work Specialists, Journal of Social Work Practice 1/2014, pp. 75-94; George KARPETIS, Advocating the Clinical Social Work Professional Identity, Journal of Social Work Practice, 1/2014, pp. 23-41; and others.

26 Cf. Kathy CHARMAZ, Constructing Grounded Theory: A Practical Guide Through Qualitative Analysis, London: SAGE, 2006. 


\section{Factors Influencing the Choice of Spiritually Formed Interventions, and the Options of Choice}

The following text is divided into three parts. In the first one (Chapter 5.1), a set of acceptable interventions will be described (taking into account those which are based on the professional discourse). Greater attention will be paid to those that are spiritually formed. In the second part (Chapter 5.2), factors which influence the choice of a specific spiritually formed intervention or of several such interventions will be described. The final, third part (chapter 5.3) briefly describes the resulting forms of interventions in terms of named factors.

\subsection{Set of Acceptable Interventions}

There are two reasons why we need to talk about a set of acceptable interventions (hereafter 'Set'). Firstly, it is precisely this area of knowledge and practical skills which provides the range of interventions for our female social workers. They chose from this Set. Secondly, it turns out that this Set is not the same for all social workers. The Set consists of interventions that are based on both professional and spiritual discourse. In the former, the contents of the Set are procedures that are customary for crisis intervention and are also acquired in crisis intervention training. It is 'a craft' which is (among other things) a set of 'techniques, such as the structure of conversation, active listening, and these things that belong to knowledge about how to conduct an interview' (r2: 016, 018). ${ }^{27}$ In the latter (based on the spiritual discourse), the interventions are integrated by social workers from their own conception of spirituality as they were not given space for such a skill during their training. If the theme of spirituality is introduced into training, it is 'rather general. It is about sects' (r3_3: 004) ${ }^{28}$ or the basic definition of 'spiritual needs during the process of dying' (r5_2: 003), or 'a little bit about that psycho-spiritual crisis ${ }^{29} \ldots$ and then we were mainly talking about how he [the lector ${ }^{30}$ manages working with people who don't take antipsychotics' (r1_1: 006). The instructions for the spiritually formed interventions and the issue of 'how to work with it in general' were not available to the communication partners in the training. Rather, it was emphasised that 'when [the client] seeks answers for those questions of faith, he should see a pastor' (r3_3: 004). Spiritually formed interventions are thus added to the Set through the integration of some aspects of private life. Considering some views which deal with the impact of the spirituality discourse on the activities of social workers, this situation is not unusual. If, according to some, there is a need to 'live values in all roles and relationships ${ }^{31}$ and to draw activities for these roles and relationships from those values (with respect to a specific person), it can be said that personal and working life (in the spiritual discourse, in the context of social work) are expected to blend. These findings are consistent with the statements of Evans and Devlin. These two authors assume that believing social workers tend to move closer to 'faith integrating professionalism' in

27 The designation $\mathrm{r} 2$ is used as an anonymous link to the conversation with the communication partner 2 . The numbers after the colon in brackets are the paragraph numbers that the ATLAS.ti program automatically generated when copying the transcript of the dialogue.

28 The number after the underscore indicates the order of the additional interview with the communication partner. For others, see the previous footnote.

29 It is a specific manifestation of the crisis. It is associated with spiritual experiences and, at first glance, it gives the impression of a psychotic disease. According to some, though, it is not. In Europe, there is no code for it in ICD. It is, therefore, often diagnosed differently and then medicated which is not entirely appropriate for this manifestation of the crisis.

30 In this way, the author marked the words that the communication partner did not mention in the quoted sentence. They were added by the author in order to make the quote clearer.

31 Michael J. SHERIDAN, Spiritual Activism: Grounding Ourselves in the Spirit, Journal of Religion \& Spirituality in Social Work: Social Thought, 1-2/2012, p. 204. 
their professional development. They assume that the knowledge base of social work is gradually extended, that is, values and experience from the spiritual life of workers are gradually added. ${ }^{32} \mathrm{As}$ with the development towards faith integrating professionalism, communication partners enrich the set of acceptable interventions based on training by those interventions and practices that are rooted in their own spirituality.

At this point, it is important to mention that the organisation itself is also involved in the Set. With regard to the scope of the text, this issue will be mentioned only briefly. Although the number of communicative partners (further referred to as CPs or CP) does not allow generalisation, it is possible to describe the difference between secular organisations and an organisation established by the Church using the sample. In the Church organisation (unlike in the secular ones) the spiritual discourse is accepted. CP r4 (004 - 010) talks about the fact that (in the history of the organisation) they had 'some kind of a prayer book. Any client could write in it if he wanted some intercession. The intercessions took place during the team meetings of social workers. The same $\mathrm{CP}$ then describes the current practice of 'moments of silence' during the meetings. 'Someone is in charge of reading something from the Bible, praying, interceding for clients. The Church (when managing some social organisation) creates space for the spiritual discourse. It is a common part of work activities. However, this space of acceptance is not always perceived as trouble-free. The $\mathrm{CP}$ doubts the fact that clients would perceive this connection with the Church as 'a sign of quality. For many clients, it is not a sign of quality, but a hanging flag. They wonder what they will say to me. They ask themselves: Will they force me to accept faith there? Will they doubt my decision if I decide to get divorced?' These potential concerns (mentioned by our CP) are in line with the possible contradictory perception of a relationship declaration given by someone to a particular church. This is highlighted by some recent research ${ }^{33} \mathrm{CPs}$ from this particular organisation differ from each other in terms of the range of spiritually formed interventions in their Set (giving their own conception of spirituality as such)..$^{34}$ Thus, it can be said (in this case and in advance) that the church as a managing entity of social institutions creates a kind of 'mycelium' which is important for the use of spiritually formed interventions. Their particular use then depends on the preference of particular workers.

Although the focus of the research did not emphasise the societal consequences of the choice of interventions (they were essentially outside the research focus), it is appropriate (in line with the idea of mycelium and individualised choices) to mention the thesis about the privatisation of religion and the 'modern religious individualism' which interprets God and thinks about Him in a subjective way, outside the influence of churches. ${ }^{35}$ The fact that the influence of churches on individuals may be rather marginal (as well as the influence on the Set, and the functioning of the CP's organisation) is also suggested by the $\mathrm{CP}$. The $\mathrm{CP}$ describes the dispute over the values of services that 'they create' ${ }^{36}$ and which are perceived as 'something which is dictated. However, there is no harmony when dealing with those values in the organisation. They are perceived (by some $\mathrm{CPs}$ ) as 'it is not this way, and it cannot be that way' (r6: 060). In the Czech context, according to

32 EVANS and DEVLIN, Client-led..., p. 16.

33 Kathleen J. MARTIN, Resistance and Change: Visual Culture, Missionization and Appropriation, In: Indigenous Symbols and Practice in the Catholic Church, ed. Kathleen J. MARTIN, Farnham: Asgate Publishing, 2010, pp. 9-38.

34 Although the scope of the text does not allow a deeper analysis, CP r6 (070) sees spiritually formed activities in personal life as a support of the relationship with God' and understands God as the one who gave freedom to Creation. Prayers for clients in specific situations do not appear in her Set. On the other hand, CP r5 (058), who is 'convinced that God affects' human lives and even in concrete situations, accepts prayers for specific clients in specific situations in the Set.

35 Michaela BARTOŠOVÁ, Mezi Bohem a církví - pluralizace náboženské zkušenosti v římskokatolické církvi, Sociální studia 3-4/2008, p. 90.

36 The term means: the church as a managing entity. 
the 2011 Census, 14 per cent of the population are members of a particular church or religious society. This fact can also play a certain role. ${ }^{37}$ This fact can reinforce the abovementioned thesis on the individualisation of spirituality and 'compartmentalisation ${ }^{38}$ (that is, the separation of the Church from other spheres of human activity even in the case of believers, and even in the case of believers' workplace). However, the research data does not allow us to consider whether the choices of specific interventions are determined by the factors described below, or whether it is the impact of the withdrawal of the churches (of their influence, and their defined spirituality) on female social workers and their work practice (that is, it is a part of the process of the compartmentalisation and privatisation of religion).

In the CPs' Sets, the following interventions can be detected. They are described in points for clarity. It is not possible to say that all communication partners have used all the spiritual interventions all the time (as it will be shown below).

- Should social workers tell a client about their faith? - that is, to present his own anchorage in spirituality. The communication partner - also referred to as CP r4 (012) - talks about the freedom to 'tell it to him (or not). It's not that I have to, or I am not allowed but it always depends on the logic' of what the client wants to know and in what way he asks about it.

- Praying for clients. CP r6 (132) describes the practice in an organisation. 'Here at our meetings, we sometimes pray for those clients.' Likewise, CP r5 (086) reports that 'it is (when considering the work) extremely important for me that I can pray for them'.

- Praying with clients. CP r5 (216) talks about the view of praying with clients which has changed for her: 'When it happened earlier, I prayed with these people and somehow I didn't think about it. And then I spoke about it with the others. Then I realised that I should not do that.' On the other hand, CP r4 (097) says that 'if the client asks me to pray with him, I will say clearly that we can. Then I do that.' CP r3 (295) does not consider prayer with the client as part of the work. A client can have a need to 'pray in the community in a biblical meaning (that is, if two or three are gathered in His name, Jesus is somehow present among them).' The CP does not understand such a prayer as a part of her work. This way, the spiritual space (this CP is also a pastor) is added to the space of crisis intervention. It is the creation of that 'community'.

- Influencing the spiritual level of clients. CP r4 (069) briefly describes her dialogue with a client about the God's acceptance. She says that 'he needed to hear from someone that he had never stopped being worthy of God's acceptance ... that this is not based on his behaviour, and that salvation is not based on our deeds but it comes from the other side.' Similarly, CP r6 (096, 098) described how she has influenced the client's conception of God. The client saw God as the one causing pain in her life. The CP responded to this by emphasising God's love. 'I have emphasised God's love, the positive things, and the fact that the client's conception of God did not make sense.' The CP supported this positive view by the history of salvation. She says that 'the client's perception does not make sense in the context of the history of salvation as it is such a medieval concept' (i.e., it is based on power).

- Mapping of the spiritual dimension of clients (even when some clients see God as a non-existing entity). CP r3 (123) describes contact with a client who considered herself to be an atheist. She was 'asking about the term atheist and about its meaning. She described her beliefs and emphasised her belief in life here. So, we talked about it, and I asked what it meant to her'. Similarly, CP

37 It is also important to mention that $45 \%$ of respondents of this census did not answer the question.

38 BARTOŠOVÁ, Mezi Bohem..., p. 93. 
r1 (063) describes her experience with such a situation. When a client 'began to talk about God and His meaning for her, I summed it up, and I talked about it. This talking about the client's spirituality is a part of the professional provision of crisis intervention. 'It should not be seen as some meeting of Church people (brothers and sisters) in that spiritual part.' (r1: 057).

- Reading spiritual texts or Bible verses. CP r4 (051) describes, in connection with the aforementioned bullet-point Influencing the spiritual level of clients, how he works with Bible. 'I really take these verses from the Bible and try to comfort him with some concrete one, with the one he needs at the moment.' Likewise, CP r3 (111) works with spiritual literature. However, this CP uses it as a basis for mapping the client's spirituality and as a way how to influence his reflexive life management: 'Well, if I mention something about faith, we talk about it and I usually mention a book. For example, I mention a book called When Bad Things Happen to Good People, and then we just talk about that book and about some interesting questions and answers in it.'

- Emphasising God as part of the client's relationship field. For example, CP r1 (117) drew a spiritual ecogram with a client. 'I drew a client in the middle of other individual characters, including God. Then I showed her relationships in this ecogram and their moves.'

The experience with one area in the bullet-points above, namely Influencing the spiritual level of clients, has led me to the need to distinguish between spiritually oriented and spiritual situational interventions. Professional sources count on the fact that spiritually oriented interventions influence the spiritual level of the client (his conception of spirituality or his relationship with God) just by the spiritual growth support. However, communication partners described another matter. They pointed out that influencing the client's spiritual level is done in order to stabilise clients and to cope with their crisis situation. Communication partner r5 (212) justifies her procedure by the need to emphasise 'that God does not want us to be afraid', by a tendency to stabilise the client. The CP does not want this false view to be 'that issue which drags them down'. Interventions, which are (in this sense) classified under the spiritually oriented social work, ${ }^{39}$ have the character of procedures used for one of their qualities - that is, professional constructed logic of work (based on scientifically conceived discourse of professionalism).

\subsection{Factors Influencing the Choice of a Particular Intervention}

The choice of specific spiritually formed interventions from a set of acceptable interventions is governed (in the case of situations described by the CPs) by the interaction of certain factors. These factors influence how close the worker is to the Role of Training Professionalism. ${ }^{40}$ In short, the spiritual level is seen as essential for CPs and their lives. It is perceived by one CP that 'faith is not some coat that I could take off when I go to work' (r5: 068). If we use this metaphor, then the degree of inclination towards the Role (that is, the role accepted by workers during contact with a particular client) can be understood or perceived as a particular type of clothing. No matter what kind of clothing represents the job for them, they start doing social work professionally dressed. However, this kind of clothing determines their choice of spiritually formed interventions. The following influences the choice of spiritually anchored interventions: ${ }^{41}$

39 Cf. DEREZOTES, Spiritually ...; KAŇÁK, Postavení..

40 The term is part of IMIS. It expresses the fact that CPs gained their insight into professionalism in the context of crisis intervention training. In such training, the accent was put on procedures based on a professional discourse. This professional discourse builds on a world which is scientifically understood.

41 With regard to other planned articles, I consider it necessary to point out that the factors are simplified (in comparison to the description in IMIS) for the sake of clarity. I think that the dynamics of choice and its logic have not been changed. 
a) the general degree of inclination towards the Role of Training Professionalism (the mentioned 'clothing', or its type);

b) the perceived needs of clients and the possibilities of their fulfilment.

In a more professional way, it would be possible to call the general degree of inclination to the Role a reflexive work plan. ${ }^{42}$ The plan is the deeper explanation of Navrátil's thesis on a reflexive life plan towards better understanding in the area of social work profession. ${ }^{43}$ In the theory of structuration and its context, it is possible to view the general degree of inclination to the Role as an element of 'ontological safety. ${ }^{44}$ It can be seen as a degree of proximity to the scientifically understood discourse of professionalism. The closer the CP concerned is to such a discourse, the more he uses only professionally formed interventions or those interventions that could be described as spiritually sensitive. For example, CP 4 perceives prayer with a client as part of a profession while CP 3 does not see it that way (see Praying with clients in the previous section).

The second factor that contributes to the choice of one of the spiritually formed interventions is the client's need and its possible fulfilment (needs perceived and detect by CPs). Perceived needs can be divided into two general areas, being either: a) the need for salvation, or b) the need to manage the situation. The possibility of fulfilling the need is then related (again in general) either to God (a), or to the interaction between the CP and her client (b). Logically, there are four possible variants that are described in Table 2 below. The table lists those interventions that were mentioned by the CPs. These were either the implemented ones or the ones mentioned by CPs' colleagues (including colleagues from other organisations).

Table 2: The Clients' Needs Perceived by CPs and the Possibility of Its Fulfilment

\begin{tabular}{|l|l|l|}
\hline $\begin{array}{l}\text { A specific need / } \\
\text { The fulfilment options }\end{array}$ & $\begin{array}{l}\text { Interactions concerning } \\
\text { God }\end{array}$ & $\begin{array}{l}\text { Interactions with people } \\
\text { (social workers with clients) }\end{array}$ \\
\hline The need for salvation & $\begin{array}{l}\text { It is not manifested in the } \\
\text { interactions with clients } \\
\text { (concerning interviews } \\
\text { with CPs) } \\
\text { The CP's assumption that } \\
\text { we will be saved regardless } \\
\text { of our actions on the earth }\end{array}$ & $\begin{array}{l}\text { The tendency to change the } \\
\text { client's spiritual level in or- } \\
\text { der to fulfil the 'conditions' } \\
\text { of salvation }\end{array}$ \\
\hline $\begin{array}{l}\text { The need to handle the } \\
\text { situation }\end{array}$ & $\begin{array}{l}\text { Praying for clients } \\
\text { Praying with clients }\end{array}$ & $\begin{array}{l}\text { Changing the spiritual } \\
\text { level in order to handle the } \\
\text { situation } \\
\text { Mapping the spiritual level } \\
\text { in order to manage the } \\
\text { situation }\end{array}$ \\
\hline
\end{tabular}

42 It could be understood as an idea of individual workers about how to help (i.e., which interventions to use for individual clients with different personal characteristics). What conditions are suitable for constructing social work practice?

43 Cf. Pavel NAVRÁTIL, Reflexivní využití teorie v procesu posouzení: Problémy posouzení životní situace v pozdně moderní době. Habilitační práce. Brno: FSS MUNI, 2009.

44 Wafa KORT and Jamel E. GHARBI, Structuration theory amid negative and positive criticism, International Journal of Business and Social Research 5/2013, p. 95. 
If the possibility of fulfilment is perceived in interaction between God and a client (and God is seen as an initiator) then it is often associated with a limited scope of a CP's intervention. In this context, CP 5 (096) states: 'I felt my limitations a lot here. I was aware of things which I can or cannot do, and that God has some control over it.' In the case of interactions with people (social workers with clients) and its fulfilment, the act of meeting needs is perceived as the possible one even with the limited scope of the CPs' intervention. CP 4 (105) describes: 'I know these verses and I identify myself with them'. At the same phase of the interview, she says: 'If a client wants exorcism because she thinks she has worked enough in the area of psychotherapy, and there are some external ones that attack her, I'll try to get her some contact. [...] I also know that it is not a ritual. There are no flames.' The difference between these two options of fulfilment is how the CPs define situations (the key for the evaluation is the extent to which is a particular situation influenced by CPs in the context of the clients' needs).

When talking about needs, CPs distinguish the need for salvation (that is, interventions that are primarily aimed at salvation as such) and the need to manage the situation. The first mentioned need was represented in the interviews in the form of a memory (one of the CPs remembered her colleague's thought. For this colleague and her work with clients (from the CP's point of view) it was characteristic to 'fight for the Truth and seek universal truth'. In this case, the workers use 'the professional means keeping in mind that the real goal is salvation', or they 'pray for the salvation' with the clients (r3: 269). In the latter case (the need to handle the situation), CPs work with spirituality (the client's spiritual level is either influenced or mapped) but the aim is to 'calm down' (r4: 063). 'It [clients' own spirituality] should not pull them down' (r5: 212).

\subsection{From Addressing God to Spirituality Exploration}

The set of acceptable interventions and the abovementioned two factors influence how work with clients is generally structured with the usage of spiritually formed interventions. With regard to the scope of the text, I present here only a basic description of the individual variants. In fact, the following three options were expressed in the interviews the most. They correspond to the perceived need - to solve and manage clients' situations: ${ }^{45}$

- Praying for clients and praying with clients, i.e., addressing God (spiritually oriented interventions).

- Changing the spiritual level of clients in order to stabilise their situation (spiritual situational interventions).

- Exploration of spirituality for easier orientation in the situation (spiritually sensitive interventions).

In the case of spiritually oriented interventions, the $\mathrm{CP}$ stresses in prayer that: 'there is someone else who cares more about the client than me'. It does not mean that the activity carried out by the $\mathrm{CP}$ was as such ineffective. The $\mathrm{CP}$ thinks, though: 'My competence ends here and now it is up to the client and God' (r4: 006). The CP sees 'the limitations ... I see what I can or cannot do, and also that God has it somehow under control' (r5: 096). Prayers, in this sense, are realised either by individual workers or (if the organisational culture allows it) also by a group of workers

45 The above-described variant of interventions at the client's spiritual level (with regard to the client's salvation) will not be described here as it is not an authentic procedure in the area of the CP's work. 
at meetings (as described by CP r4 - see chapter 5.1 above). To put it simply, God is addressed in order to manage situations. He is not understood as the sole solver of the clients' situations. He is the One who can have control over the situation (see the CP r5 and her statement), and He has other 'competencies' than those of social workers ( $r 4: 006)$.

In the case of spiritual situational interventions, the general intention of the CPs is to influence the spiritual level of clients. They use their own spirituality. CP r6 (100) describes the situation of offering one's own view of God, the concept of salvation, and God's activity here on Earth. Her aim is to explain her liberation. 'There is liberation in my activities ... what I have to do or do not have to do to feel free' in a particular crisis situation. The CP 'emphasised the love of God, the positive things'. The CP was trying to explain that 'the view [the client's view], her conception of God, does not make sense' (r6: 096). CP r4 (051) chose a similar procedure. She says: 'I normally open the Bible or start saying those verses about how God is the One who forms us in our mother's life. Neither the heights nor the depths nor human power will separate us from the Christ's love.' It was in a situation where the client's reaction to the crisis was also that he did not feel worthy of God's love. In such cases, CPs influence their clients (and their spiritual level) through their own views and conception of God or salvation. They do this not because of salvation or because of the 'right' faith. All is done in order to reduce the pressure on clients and to make the clients' spiritual level supportive rather than complicated (concerning the situation and its management).

The last variant (spiritually sensitive intervention) is, as the previous one, characterised by the client's spirituality. Specifically, the clients' spirituality 'fits into the context of [their] crisis' (r1: 067). However, clients' spirituality is (in this case) mapped and highlighted in the context of clients' situations. This process is done for workers as well (in view of the need to better understand the situation). CP r3: 121 talks about her feeling: 'I felt a great need for internal understanding, a need to map the situation'. For this reason, the spirituality of clients is not changed or intentionally influenced. CP r1 (065) talks about a way in which she 'would not influence [the client] in her belief in some way, and, at the same time, she would give her enough room for her faith' In the context of this statement, she created a 'picture of relationships' with the client. She portrayed the client 'in the middle of the picture and around the client she placed the individual characters (including God and the relationships) with their connections and intersections. This approach should help the client to 'understand her situation' (r1: 117).

\section{Conclusion}

The article focuses on the question: What factors influence Christian female social workers and their choice of spiritually formed interventions in situations where professional and spiritual discourse clashes in the context of crisis intervention? The question asked, as well as its answer, is based on broader research. This research focuses on the construction of social work practice in situations of clashes between both discourses. On one hand, the choice of a specific spiritually formed intervention is influenced by a set of acceptable interventions (that is, what the CPs consider to be interventions in the context of the professionally understood crisis intervention). On the other hand, the choice is influenced by the interaction of two factors: a) the degree of inclination towards the Role of Training Professionalism, and b) the perceived needs of the client and the possibilities of its fulfilment. To put it simply, the higher inclination to the role leads CPs towards the choice of spiritually sensitive interventions rather than towards spiritually oriented interventions. The perceived need and the possibility of its fulfilment influences the intervention 
and its process. The intervention is then conducted with several intentions: mapping the spiritual level (easier orientation in the situation for clients), influencing the spiritual level (managing the crisis state), or reaching out to God (due to the perception of one's own limited competence to affect the clients' situation).

\section{Contact}

Jan Kaňák

HTF UK

Department of Psychosocial Sciences and Ethics

Pacovská 4

14001 PRAGUE 4

honza.k@mail.muni.cz 